What Can Science, Religion, Politics, Culture and the Economy Do? : A Corpus Study of Metonymical Conceptualization Combined with Personification

\title{
Viimaranta, Johanna
}

2020-01-02

Viimaranta , J \& Mustajoki , A 2020 , ' What Can Science, Religion, Politics, Culture and the Economy Do? A Corpus Study of Metonymical Conceptualization Combined with

Personification ' , Scando-Slavica , vol. 66 , no. 1, pp. 71-85 . https://doi.org/10.1080/00806765.2020.1741025

http://hdl.handle.net/10138/335506

https://doi.org/10.1080/00806765.2020.1741025

cc_by_nc

acceptedVersion

Downloaded from Helda, University of Helsinki institutional repository.

This is an electronic reprint of the original article.

This reprint may differ from the original in pagination and typographic detail.

Please cite the original version. 
This is an Accepted Manuscript version of the following article, accepted for publication in ScandoSlavica.

Johanna Viimaranta \& Arto Mustajoki (2020) What Can Science, Religion, Politics, Culture and the Economy Do? A Corpus Study of Metonymical Conceptualization Combined with Personification, Scando-Slavica, 66:1, 71-85, DOI: $\underline{\text { 10.1080/00806765.2020.1741025. }}$.

It is deposited under the terms of the Creative Commons Attribution-NonCommercial License (http://creativecommons.org/licenses/by-nc/4.0/), which permits non-commercial re-use, distribution, and reproduction in any medium, provided the original work is properly cited. 
Johanna Viimaranta \& Arto Mustajoki

University of Helsinki

What can science, religion, politics, culture and the economy do? A corpus study of metonymical conceptualization combined with personification

\begin{abstract}
The study analyses occurrences of Russian nouns meaning 'science', 'religion', 'economy', 'politics' and 'culture' as human-like subjects. This kind of use is interpreted as an example of a conceptualization described as PERSONIFICATION-WITHMetonymy. On the basis of the fact that Russian examples work well in translation into other languages, we assume that similar conceptualization of these abstract nouns is not completely language-dependent. The study is based on the analysis of examples taken from Integrum, a large non-annotated Russian corpus. The large number of examples found in newspaper texts and documented both quantitatively and qualitatively suggests that such non-annotated corpora can be used for studying conceptualization.
\end{abstract}

Keywords: Russian, conceptualization, metonymy, metaphor, personification 


\section{Introduction}

The aim of this paper is to use a large body of linguistic data as evidence for the conceptualization of specific abstract nouns, such as the words that carry the meaning 'science', 'religion', 'economy', 'politics' and 'culture'. We are interested in contexts where abstract nouns are given the role of a subject that is capable of controlling action. Our study concerns the Russian equivalents of these words (nauka, ${ }^{1}$ religija, èkonomika, ${ }^{2}$ politika ${ }^{3}$ kul'tura), but we believe that such words are used in very similar ways in various Western languages. This is evident from how well our Russian examples work in general in English translation and also in Finnish, the native tongue of the authors.

What unites these words is that the phenomena behind them are important constituents of modern society. One may say that science / religion / economics / politics / culture plays an important role in society. A similar role is also possible at the personal level: any of the words can be placed in the context $X$ has been an important element in Irina's life. However, there are some differences between the words, such as whether or not they are associated with an institution that is 'behind' them or 'responsible for' them. For religion, this means churches or equivalent organizations. Institutions for promoting culture and science also exist; but it is more difficult to name a general institute for the economy. Big companies, banks and international economic organizations do have power in the economy as separate actors, but the frequently

\footnotetext{
${ }^{1}$ Nauka, the Russian equivalent for science, refers to all research fields in a similar way than Wissenschaft in German.

2 This Russian word means both 'economics' and 'the economy'. In most cases in the data, the word means 'the economy'.

3 This Russian word means both 'politics' and 'policy'.
} 
mentioned concept of 'market forces' does not directly refer to an institution. Our data show that the phenomenon we describe is by no means rare: we found 5,848 occurrences in Integrum, one of the largest corpora in the world.

In this paper we will first look at the theory of conceptualization and the place of abstract nouns in it. We will then present and elaborate on the method and material we have used in the study. Our research question is: What kinds of conceptualizations are involved in presenting abstract nouns as human-like actors?

\section{Conceptualization of abstract nouns}

Conceptualization, one of the basic terms in cognitive linguistics, refers to how the language user understands and categorizes the world (e.g. Langacker 2008, 30-33; Talmy 2000, 219-239). This involves focusing attention on some features and putting others conceptually in the background. Cognitive linguistics assumes that the formation and use of linguistic expressions is dependent on conceptualization. Morphology, lexis and syntax, as well as pragmatics, all have equal evidential value with regard to conceptualization. Abstract nouns offer interesting material for studying conceptualization, because the possibility of 'direct' or 'concrete' use is excluded.

It is worth noting that using nouns in the way that interests us here is not a case of polysemy, if polysemy is understood as involving different (possibly related) dictionary meanings of the same word (like dom meaning both 'house' and 'home' in Russian, or politika both 'politics' and 'policy'). Rather, a heavily context-dependent use of these nouns can be seen as an extreme case of the encyclopaedic nature of word meaning (e.g. 
Evans 2009). Each use of the nouns under scrutiny activates certain parts of their complex meaning, but it is necessary to know all these parts to understand this use. For example, we need to have an understanding of how politics functions and what kind of actors it involves in order to understand the examples where the Russian word politika is used as the subject. The conceptualization is so natural and subtle that most speakers do not even notice that an abstract noun is being used in any special way. At the same time, it is possible that many of the occurrences in corpora are such that speakers would not acknowledge or notice using them if asked, despite deeming such examples quite natural when confronted with them. The special features of such abstract nouns as nonstandard subjects have been studied previously (Mustajoki 2007a, 2007b; Mustajoki and Steksova 2008).

Commonly acknowledged processes in conceptualization include the notions of conceptual metonymy and metaphor, which have been discussed in a vast body of literature that begins with Metaphors We Live By (Lakoff and Johnson 1980). There is no consensus on whether these two phenomena differ from one another, and, if so, how they differ (on this discussion see, e.g., Barcelona 2003, 2011, 2015; Barnden 2010; Dirven and Pörings 2003; Kövecses and Radden 1998). The difference between conceptual metaphor and metonymy has been thought to lie in the theory that metaphor is a mapping between two different cognitive domains (or frames), while metonymy involves only one domain. A second explanation states that the connection between two domains is preserved in metonymy but not in metaphor. A third school of thought sees metonymies as being based on contiguity relationships, while metaphors are built on similarity. Finally, only metaphor has been seen to require structural correspondence between the domains. As aptly illustrated by John Barnden (2010), using these different 
criteria to differentiate between conceptual metaphor and metonymy gives different results even when they are applied to the same examples. The difficulty in describing the difference between metaphor and metonymy has led to the two being discussed as being dependent on one another in various ways, or as forming a continuum.

The definition of metonymy that we apply in this study is one of the most recent ones; namely, that of Antonio Barcelona (2011, 52): 'Metonymy is an asymmetric mapping of a conceptual domain, the source, onto another domain, the target. Source and target are in the same functional domain and are linked by a pragmatic function, so that the target is mentally activated.' This approach also recognizes the possibility that a metonymy may, even when clearly structured as a metonymy, be interpreted as a metaphor by a user of concrete language in a concrete situation (Barcelona 2011, 51-52). The pragmatic functions discussed in this approach to metonymy are roughly divided into three groups: the WHOLE-PART, the PART-WHOLE and the PART-PART generic types, each of which has several subtypes (Barcelona 2015). Barcelona's examples include using America when talking about the United States (WHOLE-PART metonymy, more precisely GEOGRAPHICAL UNIT FOR RELEVANT PART), referring to an intelligent person as a brain (PART-WHOLE METONYMy, the SALIENT BODY PART FOR PERSON subtype), and pen and sword in The Pen is mightier than the sword (PART-PART generic type, more precisely INSTRUMENT FOR ACTION metonymy (Barcelona 2015: 109). Although the division into these particular subtypes can be disputed, we believe that the division into three generic metonymy types is useful and we follow this classification in our analysis.

Following the criteria introduced above, when a noun is used as an agent with human qualities, the deviation from its inherent characteristics is a case of conceptual 
metonymy, not metaphor. This is because the aspect of the noun that is activated and put forth in this conceptualization is part of the same functional domain that the abstract noun represents as a whole. If we talk, for example, about science as something that can save the economy, we are talking about the results of scientific activity and their applications, not about science as a whole. Nevertheless, these results are part of the same functional domain for science. This is also a metonymy on the basis that the link between the domains is preserved in the conceptualization, i.e. the mapping is asymmetrical. Another special feature of metonymy discussed by Barcelona $(2011,15)$ is reversibility, which can also be applied here: it is possible to refer not only to the results of scientific activity as science, but also to science as the results of scientific activity. However, this reversibility neither makes the mapping symmetrical nor takes place simultaneously in both directions. If we apply this principle to our example, we can easily see that when using the noun for science to refer to its results, the whole concept of science is still needed in order to understand the conceptualization. The pragmatic function that is necessary is either CAUSE-EFFECT or AGENT-ACTION, both of which belong to the general category of PART-PART metonymies in Barcelona's classification system (2015). The notion of science presupposes the existence of scientists, scientific activity and scientific results. In this scenario, the scientists are the agents of action.

Explaining the use of the nouns as subjects through the notion of conceptual metonymy is not enough, however, because the notion of human-like capacity and its use is central in these cases. This relates these cases to another type of conceptualization, namely personification. 
The use of the notion of personification seems to be flourishing in literary studies, regardless of whether the theory of conceptual metaphor is applied or not (see Melion and Ramakers 2016); however, most metaphor/metonymy scholars seem to have lost interest in this concept. Personification can be interpreted in the following ways: as a conceptualization that is separate from metaphor and metonymy (e.g. Lakoff and Johnson 1980); as a metaphorical conceptualization (as in the metaphor identification procedure proposed by Steen et al. 2010); or as a metonymical conceptualization. Personification - attributing human characteristics to something non-human - is in a way metaphorical, because it is based on projecting the characteristics of one domain on to another, and it builds on pointing out or creating similarities between these characteristics. At the same time it is metonymical, because only those notions that bear a relation to humans can be personified; this makes the relationship between the domains one of contiguity. In addition, as in metaphor, not all the characteristics of the domain are used. Thus, we agree with the interpretation of Dorst, Mulder and Steen (2011), building on Dorst (2011), which assumes that there are, in fact, several types of personification, including one that is based on metonymy. This type (PERSONIFICATIONWiTH-METONYMY) is neither novel nor conventional; this can be confirmed by how it is recognized by subjects in a psycholinguistic experiment (Dorst, Mulder and Steen 2011). Thus, our study builds on interpreting the use of the nouns studied as PERSONIFICATION-WITH-METONYMY. 


\section{Method and material}

The methodology of corpus-based cognitive studies has been discussed in several recent papers and books (e.g. Arppe et al. 2010; Gilquin 2010, 5-23; Glynn 2010; Gries and Stefanowitsch 2006; Gries 2015). The methodology of metaphor and metonymy research, including the specific question of the use of corpora in such research, has also attracted attention in recent years (e.g. Cameron and Maslen 2010; Deignan 2005; Littlemore 2015; Steen et al. 2010; Stefanowitsch and Gries 2006). The methods described have much in common with the methodology we propose here, such as the assumption that collocation helps with identifying metaphorical or metonymical uses. What is different in our case is the use of the Integrum database, a very large nonannotated corpus, and the amount of data thus obtained.

This study uses the main part of the Integrum database, which consists of contemporary newspapers and journals. For the study, the years 2000-2013 were chosen. The database does not give the total number of words for this subcorpus but indicates its size in 'documents', i.e. the number of articles and texts, which is approximately six million. Its overall size a decade ago was estimated at 50 billion words (Mustajoki 2006), and it is growing steadily each day with the addition of new issues of hundreds of newspapers and periodicals. This means that it is not only the biggest corpus for Russian but also one of the largest corpora in the world. Integrum comprises plain text, but has some useful tools for carrying out sophisticated searches. A word can be searched for as a lexeme, in which case the search engine displays all of its uses in any form (e.g. for nauka, nauki, nauke, nauku, naukoj, etc.). One can also search for a particular form belonging to a word's paradigm (e.g. nauku). In our case, since the feminine nouns 
nauka, religija, politika, èkonomika and kul'tura have separate forms for each case and the nominative case is used primarily as the subject of the sentence, the search with the base (nominative) form gives the results we need. At the same time, millions of sentences contain these words in the nominative case. Therefore, we studied the nouns in combination with specific verbs. The verbs are given in the third person singular form; 'perf.asp.' and 'imp.asp.' denote the perfective or imperfective aspect of the verb: ljubit 'loves' imp.asp.; pomogaet 'helps' imp.asp.; pomožet 'will help' perf.asp.; pozvolit 'will allow' perf.asp.; pozvoljaet 'allows' imp.asp.; rabotaet 'works' imp.asp.; rešaet 'solves' imp.asp.; rešit 'solves' perf.asp.; trebuet 'demands' imp.asp.; and vlijaet 'influences' imp.asp. The verbs were chosen on the basis of their meaning, referring to human-like capability. In the selection of verbs two criteria were used: they frequently occur in these noun-verb combinations and they have a large distribution of subjects used with them.

The search string was formulated in a way that would find the following cooccurrences:

1. a noun occurring in the same sentence as a verb so that the noun precedes the verb with a maximum of two words between them; and

2. a noun occurring in the same sentence as a verb so that the verb precedes the noun with a maximum of three words between them.

Russian has a relatively free word order, and determiners and indirect objects of verbs are often placed immediately before the verbs. Therefore, certain frequently used collocation techniques, such as the n-gram technique, do not work as effectively as they do for many other languages. 
The search conditions we used did not guarantee that all desirable occurrences would be found, or that no undesirable occurrences would be included in our material. However, overall, the method enabled us to restrict the number of incorrect instances to an average of $10 \%$.

\section{Results}

Before analysing each verb separately, we should pay attention to two features of the verbs. The first one concerns verbal aspect, which is one of the basic categories of Russian grammar. The main difference here is that while imperfective verbs describe action in general, perfective verbs tend to imply a notion of result. This is also reflected in negative contexts - while the negation of an imperfective verb means that the action does not take place, negation of a perfective verb negates the result. In actual usage, the difference between imperfective and perfective is also highly verb-specific.

Grammatical rules impose certain restrictions on this; when the choice of aspect is dictated by the grammatical construction, in a sense the requirements of grammar neutralize the difference between the aspectual forms.

The second feature involved here is that the third person singular forms of imperfective and perfective aspects differ from each other in the fundamental sense that the imperfective form belongs grammatically to the present tense, while the equivalent form of a perfective verb belongs to the future tense. This grammatical difference is not quite as significant as it may seem, because the present tense form (the imperfective aspect) is commonly used to refer to the near future, and the future tense form (the perfective 
aspect) has some uses that refer to the present time. ${ }^{4}$

In this study, we discuss only imperfective verb forms for those verbs that do not form a regular aspective verb pair (namely, ljubit', trebovat', rabotat', vlijat') and both imperfective and perfective where these forms exist.

Table 1 indicates the absolute number of occurrences of the verb-noun combinations in the material.

Table 1. Absolute number of occurrences of the verb-noun combinations in the material.

In the next section we will first comment on the use of each verb in our material individually to show how personification combined with metonymy works.

\section{Ljubit 'loves', 'likes'}

The imperfective verb ljubit' 'to love', 'to like' is the twenty-eighth most common verb in Russian (Ljaševskaja and Šarov 2009). Compared with this, the verb is not particularly frequent in our material: it has only 209 occurrences in noun-verb pairs. As can be seen from Table 1, by far the most frequent co-occurrence in our material for 'loving' is with the noun politika 'politics/policy' (100 occurrences). Kul'tura has 60 occurrences, nauka 25, and èkonomika 22, while the combination religija + ljubit occurs only twice.

\footnotetext{
${ }^{4}$ This can be interpreted as grammatical metonymy, following the example set by Panther, Thornburg and Barcelona (2009).
} 
Ljubit' can be used to describe one's feelings and attitudes towards other people or things. It can involve personification, where the entity presented by the abstract noun is conceptualized as a human-like agent that is capable of feeling (see ex.1, where politics loves winners). At the same time, even in such cases it is possible to interpret the thing that is represented as a sentiment (liking, loving) as a demand for existence. When, for example, 'science loves precision' (ex.2) or 'the economy likes stability' (ex.3), the meaning is that precision and stability are essential characteristics of science and the economy, or that the existence of precision and stability is necessary for science and the economy to blossom.

1. A politika ljubit kak raz vot takich, ljubit pobeditelej. (Trud, 19.09.2008) 'But politics loves precisely these kinds of people - it loves winners.'

2. - Po žizni - nikakoj, - otvetil vislousyj, - no nauka ljubit točnost ${ }^{\prime}$. (Oktjabr', 15.03.2012) 'None at all in [everyday] life,' replied the man with a drooping moustache, 'but science loves precision.'

3. Rynočnaja èkonomika ljubit stabil'nost'. (Èkspert, 26.06.2006) 'The market economy likes stability.'

In the constructions with the verb ljubit' 'to love', the subject is not actively responsible for the action but experiences it. If we say that a person loves or likes someone (or something), we are mainly referring to the subject's feelings, which may then have realizations in that person's actions. This feature of the verb makes it even harder to include any types of agents other than those that are conceptualized as experiencing 
human emotions. Loving or liking presupposes that the agent is capable of emotion or preference; it is personified.

\section{Pomogaet/pomožet 'helps'}

As can be seen from Table 1, the combination of a noun with a verb denoting 'helping' is more common than a noun with 'loving' - there were 390 occurrences for the imperfective verb and 296 for the perfective verb.

For some noun-verb combinations, the number of times that the imperfective and the perfective verbs for 'helping' occur in our material is more or less the same (96 and 89 for nauka pomogaet and pomožet; 127 and 136 for politika pomogaet and pomožet; 20 and 34 for èkonomika pomogaet and pomožet). However, it is interesting that there is a significant difference in the frequency of imperfective and perfective verb forms in combination with religija (63 vs. 18 occurrences) and kul'tura (84 vs. 19 occurrences). Possibly religija and kul'tura differ from the other nouns in the sense that they are rather closely linked to certain institutions that add content to our daily lives right here and now, such as the church for religion and different cultural institutions (organizers of cultural events, libraries, museums, etc.) for culture.

The notion of 'helping' includes the idea that the subject noun has the possibility of and capacity for helping deliberately, or that its very existence helps. The personification that enables these uses consists of conceptualizing the noun as an agent that is capable of not only helping but also choosing to do so. The causal metonymy behind the personification represents a shortened version of 'the fact that there is $\mathrm{x}$ ' or 'because 
there is $\mathrm{x}$; for example, by stating that science is helping to modernize centralized traffic control (ex.4), or that the economy helps people (ex.5).

4. Nauka pomogaet modernizirovat' dispetčerskij kontrol'. (Gudok, 20.10.2010)

'Science is helping to modernize centralized traffic control.'

5. "Mir ozdorovit èkonomiku, a èkonomika pomožet ljudjam" - takov lozung Amira Pereca. (Kommersant, 11.11.2005) "Peace will revitalize the economy, and the economy will help people" - this is the slogan of Amir Peretz.'

The causal metonymy of existence as helping may not in all cases include personification, especially in the imperfective aspect, where the help is less certain, but it cannot exclude such conceptualizations either. This could explain why with the verbs meaning helping the frequency of different aspect forms is so different.

\section{Pozvoljaet/pozvolit 'allows'}

'Allowing' is by definition related to having the power to allow or not to allow, something that only humans can possess. This personification not only involves the agent that allows but also presupposes that the subordinate agent (which is allowed to do something) has human qualities. The verb pozvoljaet/pozvolit, like its equivalents in English allow and permit, can be used in two different meanings referring to 'give a permission' or 'give/open an opportunity'. The latter, more abstract meaning is typical in the noun-verb combination in hand. 
Our data includes 1,325 examples of noun-verb combinations with the imperfective, pozvoljaet, and far fewer - 503 - for the perfective, pozvolit. This means that these two combinations are the most frequent noun-verb combinations in our material. Most of the uses of pozvolit in the data occur with politika. The overall meaning is often similar to that of pomogaet/pomožet, 'helps', as illustrated by the case of science enabling Russia to become a great country (ex.6).

6. Tol’ko razvitaja nauka pozvolit Rossii stat' velikoj stranoj. ( $L D P R, 13.07 .2007)$ 'Only well-developed science will permit Russia to become a great country.'

Religija pozvoljaet is notably frequent relative to the total number of examples with religija, this combination representing about $43 \%$ of all occurrences. Meanwhile, with all the other nouns this verb is much rarer (see Table 1). Another interesting finding is that the combination religija pozvoljaet makes up $23 \%$ of occurrences with negation but only $5 \%$ of occurrences without negation. Thus, compared with the other subjects, religion more often does not permit something.

\section{Rabotaet 'works'}

Rabotat' 'to work, to function' is one of the most frequent verbs in Russian - according to Ljaševskaja and Šarov (2009), it is the sixteenth most frequent. Its 'normal' use concerns both people (Igor' horošo rabotaet 'Igor works well') and various engines or devices (Mašina/televizor ne rabotaet 'The car/TV is not working'). The verb is frequently used with the nouns we are interested in. There are more than fifty examples with each of the nouns except religija, and for 'economy' there are as many as 528. The occurrences of rabotaet in the data include sentences stating that modern science works 
at the intersection of different specializations and disciplines (ex.7), that the economy is working/functioning (ex.8), and that culture works for future perspectives (ex.9).

7. Segodnjašnjaja nauka rabotaet na styke special'nostej i disciplin. (Parlamentskaja gazeta, 09.11.2006) 'Today's science works at the intersection of specializations and disciplines.'

8. V principe, v Rossii net krizisa - èkonomika rabotaet, pokazala rost v prošlom godu na 5\%. (Vedomosti, 20.03.2012) 'In principle, there is no crisis in Russia - the economy is functioning; it showed a growth of 5\% last year.'

9. Knižnaja že kul'tura rabotaet na perspektivu, na gody vperëd. (Literaturnaja gazeta, 27.04.2011) 'As for literary culture, it works for the future, looking several years ahead.'

With the verb rabotaet, its meaning presumes action by an entity that is named by the noun involved. The kind of work or function that is expected from each specific noun is also different. The origin of the metonymic use may derive from the workings of engines rather than humans, the working being mechanically determined. Ex.8 can be interpreted as having to do with such working (functioning) and, thus, it does not include personification. Another type of use with abstract nouns is based on the notion of humans working, involving the personification of the noun. This working is not merely mechanical functioning but requires planning and aims, such as in ex.9. In some cases the use of the noun-verb combination comes close to the meaning of the verb exist: nauka rabotaet na blago strany 'science works for the good of the country' means that the existence of science is justified because it helps people to live better. This metonymy is not, nevertheless, as central as it is for verbs meaning 'helping'. 


\section{Rešaet/rešit 'solves'}

Solving problems is a characteristically human activity. In our material, the combinations with these verbs are rare, amounting to the fewest examples of all. Solutions are provided by science (43 for the imperfective vs. 15 for the perfective), politika (59 vs. 17) and èkonomika (38 vs. 10); they are provided relatively rarely by culture (15 vs. 6$)$ and very rarely by religion (1 vs. 3 ) (see Table 1$)$. The object in these sentences is, as a rule, a word like vopros 'question', problema 'problem' or zadača 'task'. Thus, contemporary science is in the process of solving a certain issue (ex.10), liberal economics solves all problems (ex.11), or a new economic policy will deal with a given number of tasks (ex.12).

10. Vot èto očen'složnyj i trudnyj vopros, kotoryj sovremennaja nauka eščë rešaet. (Ogonëk, 11.11.2002) 'Now this is a very complicated and difficult question that modern science is still trying to solve.'

11. Lozung o tom, čto liberal'naja èkonomika rešit vse problemy, a dollar vsech uravnjaet $-\mathrm{s}$ treskom provalilsja. (Zavtra, 30.07.2002) 'The slogan according to which liberal economics will solve all problems and the dollar will make everyone equal has been comprehensively discredited.'

12. Naša novaja èkonomičeskaja politika rešit sem' zadač. (Rossijskaja gazeta, 09.11.2011) 'Our new economic policy will deal with seven tasks.'

The personification involved in seeing the noun as capable of solving something builds on features from the domain of human capacities, such as reasoning and planning. The metonymy involved represents the domain of the noun as a whole for a certain activity involved in that domain. 


\section{Trebuet 'demands, requires'}

The combination of an abstract noun with the imperfective verb trebuet 'demands' is fairly common in our material (1521 occurrences altogether). The verb is often combined with èkonomika (627 occurrences), politika (403), nauka (259) and kul'tura (208), but it is rarely used with religija (24).

Demanding or requiring means that either certain conditions need to be met for the realization of something, or someone or something concretely and deliberately makes a particular demand. Both variants include a metonymical conceptualization in which existence and functioning are seen as being tantamount to the concept as a whole. When science requires more financing (ex.13) or certain policies require a new evaluation of budgeting priorities (ex.14), the sentence is making a statement about the progress and development of this societal activity at a specific moment. Another kind of use considers the essence and existence of culture by stating that a great culture requires effort (ex.15). In both kinds of uses personification plays a central role - as an activity, demanding presupposes a conscious choice that can be made only by humans.

13. Osnovnaja naša beda svjazana s gosudarstvom, kotoroe ne ponimaet, čto nauka trebuet uveličenija finansirovanija. (Izvestija, 20.07.2011) 'Our main trouble is with the State, which does not understand that science demands an increase in funding.' 14. Takaja politika trebuet peresmotra osnovnych prioritetov federal'nogo bjudžeta. (Trud, 16.04.2008) 'Such a policy requires a reconsideration of the main priorities of the federal budget.' 
15. Voobšče velikaja kul'tura - ona trebuet usilija. (Rossijskaja gazeta, 01.03.2013) 'In general, a great culture requires effort.'

\section{Vlijaet 'influences'}

In the data, the noun politika (299 occurrences) accounts for more than half of all the uses of the verb form vlijaet 'influences' (485 altogether). Politics is conceptualized, for example, as having a direct effect on business and the actors involved in it (ex.16). With some of the nouns this verb is uncommon, especially with nauka (22 occurrences). One could have expected science to be seen as a major influencer, but the material does not confirm this assumption. Ex.17 is a typical example: science as an influencer is justified separately.

16. Pora priznat', čto politika prjamo vlijaet na biznes: na nas samich, sotrudnikov, reguljatorov rynka, pravoochranitelej. (Novye Izvestija, 08.08.2013) 'It is time to admit that politics directly influences business - ourselves, employees, market regulators, and law enforcers.'

17. Podčerknëm, čto naibolee èffektivno fundamental'naja nauka vlijaet na razvitie čerez obrazovanie, i poètomu tak važna integracija učënych s universitetami. (Èkologija

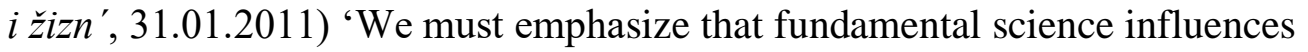
development most effectively through education, and this is what makes the integration of researchers with universities so important.'

18. No nel'zja zabyvat', naskol'ko politika vlijaet na rešenija ob investicijach v Kitae. (Èkspert, 22.10.2012) 'But we mustn’t forget to what extent politics influences the decisions concerning investments in China.' 
As a metonymy, politika can refer to people engaged in politics, i.e. politicians

(INSTITUTION For PEOPLE). Such uses are rare in our data, however, although without a wider context it can be impossible to understand precisely what politics is, such as in ex.18. Influencing something does not necessarily require a conscious effort and, thus, personification; it may also refer metonymically to the fact that the mere existence of one entity has an impact on another.

\section{Conclusion}

While the abstract nouns studied are similar in that they all represent significant entities for modern society, the frequency differs for each noun-verb pair in our material. This partly reflects the level of importance of these conceptualizations in our lives, although naturally, it is also related to how frequently the topics are discussed in newspapers. Nevertheless, the noun-verb combinations that do not occur or have very few occurrences in our enormous volume of material are taken here to provide evidence that these combinations are not central to our conceptualization. If we compare the absolute numbers of occurrences of the abstract nouns and take into account the typical predicates for them, the most powerful forces in society seem to be politics and economics. Politics very often allows, and economics demands. Science and culture are also conceptualized as significant agents, and they both most frequently demand something. Religion, on the other hand, is used surprisingly rarely in such conceptualizations.

Although in many cases the use of an abstract noun as a subject can be seen to involve attributing human characteristics to that abstract noun, the notion of personification 
does not fully explain this type of usage. The use of abstract nouns as subjects is connected to a metonymical conceptualization of the WHOLE-PART type. The abstract noun used as the subject represents the whole, but what is actually meant by it is part of this whole. The conceptualizations are clearly metonymic, meeting all the criteria introduced in the literature on conceptual metonymy and discussed above. The use of each noun as an agent introduces a certain part of the meaning of the noun as representing the entire abstract meaning. The abstract meaning as a whole and its more concrete part belong to the same conceptual domain; as a result they do not involve a metaphorical transfer from one domain to another, but a metonymic conceptualization. This conceptualization preserves the connections between the original domain and the part of it that is used.

The exact way in which personification is combined with metonymy depends on whether or not in the concrete use the abstract noun refers primarily to an institution or organization. Such an interpretation would explain the way that although the nouns included here seem to be similar in how they function, our material showed significant differences in the frequency of different combinations and the way that imperfective and perfective verbs were used with them. These differences offer new information about components of meaning that go beyond the grammatical aspect system in the use of different verbs. Besides the use of nouns in a way that indicates a metonymical conceptualization, the use of the noun-verb combinations studied is a case of metonymy combined with personification. This involves an ability to act in a way that is typical of humans. In this case, the acting capacity of the noun refers to the human-like characteristics attributed to it. For example, the people who create and damage culture are both makers and objects of culture. 
Personification can be interpreted as a kind of metaphor in which an abstract noun is conceptualized as having human characteristics. Nevertheless, personification is specific and can also involve metonymy, as it does in this case. Therefore, we believe that personification should be dealt with as a conceptualization that is separate from metaphor and metonymy but can co-occur with them. In this metonymy the abstract noun stands for the existence of the abstract notion indicated by it and in individual uses any of the possible parts of the complex such as the institutional or organizational information related to the abstract notion as a part of its encyclopaedic meaning can be combined with or compete with the conceptualization as personification. The differences in how the noun-verb combinations studied work are, according to our analysis, related to the way that a certain conceptualization reflected in language use highlights certain related features of the abstract noun. This is combined with the verb meaning that has certain grammatical features but is semantically realized only in context.

\section{References}

Arppe, A., G. Gilquin, D. Glynn, M. Hilpert, and A. Zeschel. 2010. "Cognitive Corpus Linguistics: Five Points of Debate on Current Theory and Methodology." Corpora $5(1): 1-27$.

Barcelona, A., ed. 2003. Metaphor and Metonymy at the Crossroads: A Cognitive Perspective. Berlin: Mouton de Gruyter.

Barcelona, A. 2011. "Reviewing the Properties and Prototype Structure of Mmetonymy." In Defining Metonymy in Cognitive Linguistics. Towards a Consensus 
View, edited by R. Benczes, A. Barcelona, and F. J. Ruiz de Mendoza Ibáñez, 8-58. Amsterdam/Philadelphia: John Benjamins.

Barcelona, A. 2015. "Metonymy." In Handbook of Cognitive Linguistics, edited by E. Dąbrowska and D. Divjak, 106-122. Berlin, Germany: De Gruyter Mouton.

Barnden, J. A. 2010. "Metaphor and Metonymy: Making Their Connections Mmore Slippery." Cognitive Linguistics 21(1):1-34.

Cameron, L. and Maslen, R., eds. 2010. Metaphor Analysis: Research Practice in Applied Linguistics, Social Sciences and the Humanities. London: Equinox.

Deignan, A. 2005. Metaphor and Corpus Linguistics. Amsterdam: Benjamins.

Dirven, R., and R. Pörings, eds. 2003. Metaphor and Metonymy in Comparison and Contrast. Berlin: Mouton de Gruyter.

Dorst, A. G. 2011. Personification in Discourse: Linguistic Forms, Conceptual Structures and Communicative Ffunctions. Language and Literature 20 (2):113-135.

Dorst, A. G., G. Mulder and G. J. Steen. 2011. "Recognition of Personifications in Fiction by Non-expert Readers." Metaphor and the Social World 1(2):174-200.

Evans, V. 2009. How Words Mean: Lexical Concepts, Cognitive Models, and Meaning Construction. Oxford: Oxford University Press.

Gilquin, G. 2010. Corpus, Cognition and Causative Constructions. Amsterdam: John Benjamins.

Glynn, D. 2010. “Corpus-driven Cognitive Semantics. An Introduction to the Field.” In Corpus-driven Cognitive Semantics: Quantitative approaches, edited by D. Glynn and K. Fischer, 1-42. Berlin: Mouton de Gruyter.

Gries, S. Th. 2015. "More (Old and New) Misunderstandings of Collostructional Analysis: On Schmid and Küchenhoff (2013).” Cognitive Linguistics 26(3):505-536.

Gries, S. Th. and A. Stefanowitsch,eds. 2006. Corpora in Cognitive Linguistics: Corpus-Based Approaches to Syntax and Lexis. Berlin: Mouton de Gruyter. 
Kövecses, Z. and G. Radden. 1998. "Metonymy: Developing a Cognitive Linguistic View.” Cognitive Linguistics 9-1:37-77.

Lakoff, G. and M. Johnson. 1980. Metaphors We Live By. Chicago: University of Chicago Press.

Langacker, R. W. 2008. Cognitive Grammar: A Basic Introduction. New York: Oxford University Press.

Littlemore, J. 2015. Metonymy: Hidden Shortcuts in Language, Thought and Communication. New York: Cambridge University Press.

Ljaševskaja, O. N. and S. A. Šarov. 2009. Častotnyj slovar' sovremennogo russkogo jazyka (na materialach Nacional'nogo korpusa russkogo jazyka) [Frequency dictionary of Modern Russian (based on material of Russian National Corpus)]. Moscow:

Azbukovnik.

Melion, W. S. and B. A. M. Ramakers, eds. 2016. Personification: Embodying Meaning and Emotion (Intersections; v. 41.) Leiden, The Netherlands: Brill.

Mustajoki, A. 2006. "The Integrum Database as a Powerful Tool in Research on Contemporary Russian” In Integrum: točnye metody i gumanitarnye nauki, edited by G. Nikiporec-Takigava, 50-75. Moscow: Letnij sad.

Mustajoki, A. 2007a. "Razmyšlenija o vozmožnostjach nauki (zametki na poljah Russkogo semantičeskogo slovarja).” In Jazyk kak materija smysla. Sbornik statej v čest' akademika N. Ju. Švedovoj, 72-78. Moscow: Azbukovnik.

Mustajoki, A. 2007b. "What Can Literature Do?” In Varietas et Concordia. Essays in Honour of Professor Pekka Pesonen On the Occasion of His 60th Birthday, edited by B. Hellman, T. Huttunen and G. Obatnin, 64-75. Helsinki: Department of Slavonic and Baltic Languages and Literature.

Mustajoki, A. and T .I. Steksova. 2008. “Nabljudenija nad nestandartnymi Sub”ektami: čto mogut delat' nauka, politika i èkonomika." Sibirskij filologičeskij žurnal 2/2008:193-209. 
Panther, K.-U., L. L Thornburg and A. Barcelona, (Eds). (2009). Metonymy and Metaphor in Grammar. Amsterdam: John Benjamins.

Steen, G. J., A. G. Dorst, J. Berenike Herrmann, A. A. Kaal, T. Krennmayr and T. Pasma, eds. 2010. A Method for Linguistic Metaphor Identification. Amsterdam: John Benjamins.

Stefanowitsch, A. and Th. Gries, eds. 2006. Corpus-Based Approaches to Metaphor and Metonymy. Berlin: Mouton de Gruyter.

Talmy, L. 2000. Toward a Cognitive Semantics. Vol. I. Concept Structuring Systems. Cambridge, MA: MIT Press. 